\section{COVID-19's Impact on the Student Learning Process in Rwandan Higher Education Institutions}

\author{
Daniel Twesige, Faustin Gasheja, Kadhafi Isae Misago and \\ Eugen Muvunyi
}

\begin{abstract}
The coronavirus pandemic has not only challenged health systems, but has also had a significant impact on education systems across the globe. This study analysed COVID-I9's impact on the student learning process in higher education institutions in Rwanda. A quantitative research design was adopted and pragmatism was selected as the research philosophy. Primary data was collected from I I7O students in 30 institutions using a closed-ended questionnaire. The data was analysed using descriptive and inferential statistical tools. The results indicate that the pandemic has led to changes in the academic calendar, suspension of examinations, and finalyear students being unable to conduct research and serve internships. It has also affected the quality of learning and learning from peers due to social distancing. Students in rural areas and those from vulnerable families have been worst affected.
\end{abstract}

Key words: COVID-I9, learning, higher education institutions, online learning, students

La pandémie de coronavirus a non seulement mis à l'épreuve les systèmes de santé, mais a également eu un impact significatif sur les systèmes éducatifs à travers le monde. Cette étude analyse l'impact du COVID-I9 sur le processus d'apprentissage des étudiants dans les établissements d'enseignement supérieur au Rwanda. Un plan de recherche quantitatif a été adopté et le pragmatisme a été choisi comme philosophie de recher-

ABOUT THE AUTHORS: DANIEL TWESIGE, University of Rwanda. Email: twesiged@yahoo.com FAUSTIN GASHEJA, University of Rwanda. KADHAFI ISAE MISAGO, University of Rwanda and EUGEN MUVUNYI, University of Rwanda. che. Des données primaires ont été recueillies auprès de I,I70 étudiants de 30 établissements à l'aide d'un questionnaire fermé. Les données ont été analysées à l'aide d'outils statistiques descriptifs et inférentiels. Les résultats indiquent que la pandémie a entraîné des changements dans le calendrier scolaire, la suspension des examens et l'incapacité des étudiants de dernière année de mener des recherches et de faire des stages. Elle a également diminué la qualité de l'apprentissage et réduit la fréquence de l'apprentissage des pairs en raison du besoin de la distanciation sociale. Les élèves des zones rurales et ceux en provenance de familles vulnérables ont été les plus touchés.

Mots clés: COVID-I9, apprentissage, établissements d'enseignement supérieur, apprentissage en ligne, étudiants

\section{Introduction}

School closures are one of the non-pharmaceutical measures that were introduced to control the spread of COVID-I9. Following the identification of the first case of COVID-I9 in Rwanda on I4 March 2020, the government took immediate steps to control its spread. Among the first measures that were announced on I5 March were the closure of schools and churches. These were followed by other measures such as social distancing, a total lockdown and the wearing of face masks.

These measures led to many higher education institutions (HEIs) shifting the teaching and learning process (teaching, learning and assessment) from normal classrooms (face-to-face) to virtual classrooms (online teaching) through the use of various technologies. Although online learning is a common trend in this new technological era, scholars such as Naciri et al. (2020), Bao (2020), Reimer and Schleicher (2020), and Sintama (2020) observe that it confronts a number of challenges such as a lack of infrastructure to support online learning, and poor network connections.

The COVID-I9 pandemic has created a number of challenges in the learning process of students in HEIs. Huston et al. (2020) and Peters et al. (2020) note that COVID-I9 interrupted the learning process of students in hard sciences subjects due to a lack of virtual laboratories, cadavers, dissection rooms, specimens, skeletons, and practical learning material. Ogunode et al. (2020), Wargadinata et al. (2020) and Daniel (2020) highlight that it disrupted the academic calendar, with students unable to complete their studies on time. Wargadinata et al. (2020), Owusu et al. (2020), Drane et al. (2020), Calhoun (2020) and Caoa et al. 2020) observe that many students lack skills to study and practice online. Furthermore, many live in homes that do not offer a conducive study environment. Finally, COVID-Ig has meant that students are missing out on learning from others through group discussions.

Reimers and Schleicher (2020) and Toquero (2020) point out that the 
lockdowns imposed as a result of COVID-I9 prevented final-year students from gathering data for their research projects. The pandemic also disrupted assessment, which is one of the key activities in the teaching and learning process, as it evaluates whether students have acquired the relevant knowledge and skills. As noted by Reimers and Schleicher (2020) and Joseph et al. (2020) many HEIs did not develop online curricula to facilitate the online learning process. This severely affected many HEIs' internal assessment processes.

While there is a rich body of emerging literature on COVID-Ig's impact on education in different countries (Zhanga et al., 2020; Radwan and Radwan, 2020; Connorchick et al., 2020; Karalis, 2020; Brown et al., 2020; Reimers and Schleicher, 2020), limited research has been conducted in Rwanda. Moreover, most studies that have analysed this phenomenon have relied on secondary data (Connorchick et al., 2020; Zhanga et al., 2020; Ozer, 2020; Ogunode et al., 2020; Peters et al., 2020; Karalis, 2020). This study contributes to the existing literature in two important ways; firstly, by focusing on the impact of the COVID-I9 pandemic on the learning process in Rwanda and secondly, by adding to the methodological approach by adopting the research philosophy of pragmatism.

\section{Literature review}

The coronavirus pandemic which started in Wuhan, China in December 20I9 has not only challenged health systems, but has had a significant impact on education systems across the globe (Owusu et al., 2020, Daniel, 2020; Chan, 2020; Peters et al., 2020; Karalis, 2020). The measures adopted to combat COVID-I9 such as lockdowns, social distancing and quarantine have disrupted the operations of education institutions (Daniel, 2020; Ognodi et al., 2020; Reimers and Schleicher, 2020). Teaching shifted from physical to virtual classrooms and from schools to homes (Zhanga et al., 2020). This has not only affected teaching and learning processes, but also threatened the survival of private education institutions that rely solely on fees from students (Karalis, 2020).

While online learning appears to be a solution in situations where the normal learning process cannot take place (Wargadinata et al., 2020), it has raised numerous challenges. Daniel's (2020) survey of different education institutions in the United Kingdom used a questionnaire which was emailed to the respondents. The findings show that COVID-I9 has impacted on students in different ways, including delays in final-year students completing their studies, employment challenges, and inability to complete the school curriculum and conduct rigorous assessment. Zhanga et al.'s (2020) study examined the suspension of classes while continuing learning and China's education management policy during the pandemic. The qualitative study which relied on secondary sources revealed that the learning process has been affected by poor online teaching infrastructure, inexperienced teachers, unequal learning outcomes due to inexperienced teachers, a complex home environment and ineffective use of online teaching resources. It also noted that, both teachers and students confront problems in teaching and learning online due to unclear teaching modes and pedagogy.

Chan's (2020) research on COVID-I9 and global higher education adopted a qualitative approach, with the data comprising I23 abstracts. It found that the pandemic negatively impacted the academic calendar. Murphy (2020) focused on eLearning and the implications of the securitisation of higher education for post-pandemic pedagogy. The qualitative study that relied on a literature review showed that securitisation theory is an important tool for educators in relation to emergency eLearning and the author advocated for the de-securitisation of schools after COVID-I9.

Naciri (2020) examined the role of mobile learning as a remote teaching strategy in sustaining student-centred learning. Mobile learning enables learning at any time and place. The author notes that the COVID-I9 pandemic has highlighted the potential of teaching innovations. However, there are also significant challenges in terms of developing students' technological skills to use e-Learning. Doyle (2020) analysed COVID-I9's impact on education inequality in Ireland. A systematic qualitative review was conducted of 45 studies modeling the effect of COVID-I9 on schools. The findings revealed that the pandemic has widened education inequality.

Abidah et al. (2020) analysed COVID-Ig's impact on the Indonesian education sector through a conceptual analysis of various research articles. The findings point to a lack of learning resources, digital classes, and virtual laboratories during the pandemic. Aziz and Ojcius' (2020) literature review investigated COVID-Io's impact on dental education in the United States (US). The study found that the pandemic has impacted the teaching and learning process, with graduations delayed or moved online and parents having to assist their children with online learning.

Wargadinata et al. (2020) analysed the learning experiences of $225 \mathrm{stu}$ dents at HEIs in Malang, Indonesia during COVID-I9 using an online questionnaire. The study found that students preferred WhatsApp groups as the App does not require much data and is simple to use. Education institutions adopted different learning models to ensure continuous learning, including WhatsApp groups, e-learning platforms, Zoom, Google classrooms, Microsoft teams, WebEx and others. Huston et al. (2020) examined the impact of the COVID-I9 pandemic on medical students in the US. The qualitative study found that the fact that students were sent home and removed from hospital and clinic settings, and shifted from live groups to virtual teaching affected their acquisition of practical skills. 
Owusu et al.'s (2020) research on COVID-I9's impact on learning in Ghana surveyed 2I4 students at tertiary institutions using a questionnaire. The challenges identified included not being able to study effectively, parents' lack of skills to assist their children with online learning, limited access to the Internet, and a lack of technological knowhow. Drane et al. (2020) analysed the impact of online learning on the educational outcomes of vulnerable children in Australia during the COVID-I9 pandemic. The qualitative study pointed to limited skills in the use of technology during the learning process, limited Internet coverage and a lack of data, and less learning from others through group discussions. The researchers concluded that offsite learning and the loss of school connectedness may negatively impact students' emotional wellbeing and heighten anxiety.

Calhoun (2020) focused on medical students' surgical education during the pandemic in the US and found that it limited their ability to acquire practical skills. Caoa et al.'s (2020) research on COVID-Io's psychological impact on the college students in China administered a questionnaire to 7 I43 students. The findings revealed that living with one's parents, a stable family income, and residing in an urban area reduced students' levels of anxiety during the pandemic.

Kapasiaa et al.'s (2020) online survey of the learning status of undergraduate and postgraduate students during the COVID-I9 pandemic in India covered 232 students. It concluded that students from remote areas and those that were marginalised faced the most severe challenges Daroedono et al. (2020) analysed the impact of COVID-I9 on medical education based on students' perceptions and practice of long distance learning in Indonesia. The study used a cross-sectional design and covered 545 students from medical schools. The findings revealed that a lack of virtual laboratories negatively affected the learning process.

This brief literature review highlights the efforts made by researchers to analyse COVID-Ig's impact on students' learning process across the globe. While these studies yield valuable insights, they may not apply to the Rwandan context. It is against this background that our study focused on the COVID-I9 pandemic's impact on Rwandan students' learning process.

Secondly, the existing literature provides little evidence on the inequality created by COVID-I9 among students based on their location, in particular, the differences between rural and urban areas. Previous studies have noted that a lack of Internet connections, electricity and infrastructure that supports online learning hamper virtual learning (Drane et al., 2020; Owusu et al., 2020). However, comparisons have not been made to show which countries have been most affected by these challenges. Learning inequality arises when some areas of a country and sections of the population has greater access to education than others (Caoa et al., 2020). This study contributes to the existing literature by establishing the impact of the COVID-I9 pandemic based on students' location.

\section{Methodology}

This study analysed how the COVID-I9 pandemic affected the learning process of students in Rwandan HEIs. The following methods and techniques were employed to collect and analyse the data.

Research approach and design

This research was guided by the pragmatism research philosophy and a quantitative research design. A quantitative research design has been adopted by many studies on COVID-Ig's impact on education (Daroedono et al., 2020; Kapasiaa et al., 2020; Caoa et al., 2020). Twesige et al. (2020) point out that if a study requires the use of questionnaires, a quantitative research design is the best technique.

\section{Study population and sampling}

The study population was drawn from Rwandan HEIs. According to the Higher Education Council (HEC) (2020), there are 30 such institutions in the country, including two public and 28 private institutions. The target population was students from different programmes offered by HEIs on different campuses. However, it is important to note that the University of Rwanda has nine campuses across the country. Therefore, each campus was considered as an independent university. The number of universities surveyed was thus 29 plus these nine campuses, bringing the total to 38. Thirty students were selected from each campus to form the sample. Therefore, the target sample was $(38$ x 30) I I7 8 students selected from both towns and rural areas. A purposive sampling technique was used to select the students from three clusters, namely, Kigali city, towns and rural areas.

\section{Data collection}

Data was collected from primary sources using questionnaires. A closeended questionnaire using a Likert scale was emailed to students through their head of department and class representatives. A questionnaire was deemed appropriate due to the advantages it offers over other instruments (Kasomo, 2006; Grafton et al., 20II; Twesige et al., 2020). Given restricted movement and social distancing during COVID-I9, an online questionnaire was particularly appropriate. A pilot study was conducted with students from the Department of Accounting at the University of Rwanda to ensure the reliability of the instrument. The reliability was tested using a Cronbach alpha test, which indicated an alpha of $87 \%$, showing that the instrument was reliable and could be used to achieve the study's objectives. 


\section{Data analysis}

A total of I I78 questionnaires were distributed to the respondents and I Ioo were returned, representing a return rate of $93.4 \%$. These included 479 students from rural areas, 334 from towns and 287 from Kigali city. After receiving the completed questionnaires, a template was designed in the Statistical Package for the Social Sciences (SPSS) which was used for data entry. After data entry and cleaning, descriptive and inferential statistical tools were used to analyse the data. Descriptive data analysis was conducted using frequency tables, mean and standard deviation. The inferential data analysis was conducted using ANOVA and the Kruskal Wallis Test. ANOVA was used to test the significance of the impact of the COVIDI9 pandemic on students' learning process in Rwandan HEIs. The Kruskal Wallis test was used to determine the areas that were most affected by the pandemic and to test the significance of the challenges it posed to students' online learning.

\section{Operationalisation of variables}

The independent variable was the learning process. As per the HEC academic guidelines, the learning process includes teaching and learning, and assessment strategies. Before the COVID-I9 pandemic the learning process was through normal classrooms (face-to-face). However, due to COVID-I9 restrictions, it was shifted to virtual classrooms (online). In this study, the learning process was measured by whether students accessed online learning, whether they were able to learn effectively using online platforms, and whether they had devices to help them online. The impact of COVID-I9 was measured by the challenges caused by the shift from face-to-face to online learning.

\section{Results and discussion}

This section presents and discusses the results from the survey

Table 1: Mode of Learning during the COVID-19 pandemic

\begin{tabular}{|l|c|c|c|c|c|}
\hline $\begin{array}{l}\text { Tools used in online } \\
\text { learning }\end{array}$ & $\begin{array}{l}\text { Strongly } \\
\text { Disagree \& }\end{array}$ & $\begin{array}{l}\text { Disagree } \\
\%\end{array}$ & Neutral \% & Agree \% & $\begin{array}{l}\text { Strongly } \\
\text { Agree \% }\end{array}$ \\
\hline Moodle online platform & & & & 22 & 78 \\
\hline Video conferencing & 57 & 15.2 & 9.6 & 8 & 10.3 \\
\hline $\begin{array}{l}\text { Moodle and video } \\
\text { conferencing }\end{array}$ & 46.6 & 22.7 & 11.5 & 18.2 & 1 \\
\hline WhatsApp groups & & & 30 & 65 & 5 \\
\hline WhatsApp and Moodle & & & 35.6 & 50.4 & 14 \\
\hline
\end{tabular}

Table I shows that all the respondents studied using an online Moodle platform; while $72.2 \%$ of the students did not use video conferencing, with I $8.3 \%$ using this tool; and $9.6 \%$ of the respondents remaining neutral on this question. Furthermore, $69.3 \%$ of the students disagreed, II.5\% were neutral and I9.2\% agreed that they used both the Moodle platform and video conferencing during their learning process. The results further revealed that $70 \%$ of the respondents used WhatsApp to support their learning process, whereas $30 \%$ were neutral. Finally, $64.4 \%$ of the students used both Moodle and WhatsApp to support their learning process.

These findings thus show that learning shifted from face-to-face to online classrooms during the COVID-I9 pandemic using different learning platforms. This concurs with the findings of previous studies (see, for example, Zhanga et al., 2020; Wargadinata et al., 2020 and Daniel, 2020). The results also illustrate that the Moodle e-learning platform was the most used by students, followed by WhatsApp. The findings reveal limited use of video conferencing to support the learning process by students. The use of WhatsApp has been fundamental in supporting group discussions and interactive learning by students. Owusu et al. (2020) also found that WhatsApp was used in Ghana to support online learning through interactive learning and group discussions.

Table 2: Student attendance

\begin{tabular}{|l|l|c|c|c|}
\hline & & Frequency & Percent & $\begin{array}{l}\text { Cumulative } \\
\text { Percent }\end{array}$ \\
\hline \multirow{3}{*}{ Valid } & Every day & 309 & 28.1 & 28.1 \\
\cline { 2 - 5 } & Once a week & 348 & 31.6 & 59.7 \\
\cline { 2 - 5 } & Twice a week & 96 & 8.7 & 68.4 \\
\cline { 2 - 5 } & Three times a week & 25 & 2.3 & 70.6 \\
\cline { 2 - 5 } & Never attended & 322 & 29.4 & 100 \\
\cline { 2 - 5 } & Total & 1100 & 100 & \\
\hline
\end{tabular}

Source: Survey Data, 2020

Table 2 shows how often the students attended online classes. It reveals that $28.1 \%$ attended online classes every day; 3 I.6\% once a week; $8.7 \%$ twice a week; $2.3 \%$ three times a week and $29.4 \%$ of the respondents never attended online classes. The findings clearly illustrate COVID-Ig's impact on student attendance of classes as only $28.1 \%$ of the surveyed students attended their classes on a daily basis. They concur with those of previous studies that point to students' poor attendance of online classes (see Daroedono et al., 2020; Caoa et al., 2020 and Kapasiaa et al., 2020). This 
not only results in low skills acquisition, but also leads to learning inequality among students.

Table 3: Devices used by students during the online process

\begin{tabular}{|l|l|c|c|c|}
\hline & & Frequency & Percent & $\begin{array}{l}\text { Cumulative } \\
\text { Percent }\end{array}$ \\
\hline Valid & Smart phone & 646 & 58.7 & 58.7 \\
\cline { 2 - 5 } & Laptop & 263 & 23.9 & 82.6 \\
\cline { 2 - 5 } & Laptop and smartphone & 149 & 13.5 & 96.1 \\
\cline { 2 - 5 } & IPad & 39 & 3.5 & 99.7 \\
\cline { 2 - 5 } & Internet café & 3 & .3 & 100 \\
\cline { 2 - 5 } & Total & 1100 & 100 & \\
\hline
\end{tabular}

\section{Source: Survey Data, 2020}

Table 3 shows that $58.7 \%$ of the respondents used smartphones during online learning; $23.9 \%$ laptops; $13.5 \%$ laptops and smartphones; and 3.5\% IPads, while $0.3 \%$ visited an Internet café in order to access online learning. They thus show that the majority of the students used smartphones to access learning platforms. While the fact that the majority of these students could at least access learning platforms using smartphones might be regarded as good news, smartphones are somewhat complicated for students to use to complete assignments, especially those that are quantitative. This further impacts the quality of the learning process. Furthermore, Huston et al. (2020) assert that a lack of technological tools impinges on students' learning process.

Table 4: Challenges faced by students during Online Learning

\begin{tabular}{|l|l|c|c|c|}
\hline \multirow{2}{*}{} & & \multicolumn{3}{|c|}{ \% within Location } \\
\cline { 3 - 5 } & & Rural Areas & Towns & City of Kigali \\
\hline $\begin{array}{l}\text { Challenges } \\
\text { faced } \\
\text { during } \\
\text { online } \\
\text { learning }\end{array}$ & Lack of computers & 75.6 & 18 & 6.4 \\
\cline { 2 - 5 } & Lack of sufficient skills to learn online & 75 & 65 & 70 \\
\cline { 2 - 5 } & Lack of electricity & 60 & 25 & 15 \\
\cline { 2 - 5 } & Home environment was not conducive & 65 & 70.2 & 65.8 \\
\cline { 2 - 5 } & Lack of data & 50.9 & 36.8 & 12.3 \\
\cline { 2 - 5 } & Poor Internet connection & 79.6 & 41.1 & 39.3 \\
\cline { 2 - 5 } & Studying without doing exams & 78 & 62 & 80 \\
\cline { 2 - 5 } & Learning platform not sufficient & 82.9 & 69.4 & 57.6 \\
\hline
\end{tabular}

Table 4 sets out the challenges that students confronted while studying online. It shows that $75.6 \%$ of the respondents in rural areas had no access to computers, compared to $18 \%$ and $6.4 \%$ of those in towns and Kigali city, respectively. The results also reveal that $75 \%, 65 \%$ and $70 \%$ of the respondents from rural areas, towns and the city of Kigali, respectively, lacked sufficient skills to study online. Furthermore, $60 \%$ of the respondents in rural areas reported a lack of electricity, compared to $25 \%$ and $15 \%$ of those in towns and Kigali city, respectively. Turning to the conduciveness of the home environment, the results show that $65 \%$ of the respondents from rural areas indicated that their home environment was not conducive to studying, compared to $65 \%$ and $70 \%$ of those in towns and the city of Kigali, respectively. The table reveals that $50.9 \%$ of the students lacked data to engage in online learning, while the figures for towns and the city of Kigali were $36.8 \%$ and $12.3 \%$, respectively.

Another challenge that confronted these students in studying online was poor Internet connections. The findings illustrate that $79.6 \%$ of the respondents in rural areas experienced this problem, compared to 4 I.I\% and $39.3 \%$ in towns and the city of Kigali. Both summative and formative examinations are used to assess students' learning status. In order to combat the spread of COVID-I9, social distancing measures were introduced. This led to the closure of schools and students were thus unable to sit for their exams. Table 4 above shows that $78 \%$ of the respondents from the rural areas were concerned about studying without sitting for exams compared with $62 \%$ from towns and $80 \%$ from the city of Kigali. Finally, $82.2 \%, 69.4 \%$ and $57.6 \%$ of the respondents from rural areas, towns and the city of Kigali, respectively, agreed that learning infrastructure was insufficient to support effective learning.

In summary, the challenges confronted by the respondents in studying online during the COVID-I9 pandemic included a lack of computers, insufficient skills, poor Internet connections, a lack of data, lack of learning from peers through group discussions, lack of face-to-face clarification, insufficient learning infrastructure like virtual laboratories and a poor home learning environment. These findings concur with those of previous studies (Kapasiaa et al., 2020; Drane et al., 2020; Owusu et al., 2020; Abidah et al., 2020). 
Table 5: Ranking of the most affected students

\begin{tabular}{|l|l|c|c|}
\hline & Location & N & Mean Rank \\
\hline $\begin{array}{l}\text { Challenges faced } \\
\text { during online learning }\end{array}$ & Rural Areas & 479 & 189.44 \\
\cline { 2 - 4 } & Towns & 334 & 158.03 \\
\cline { 2 - 4 } & City of Kigali & 287 & 131.38 \\
\cline { 2 - 4 } & Total & 1100 & \\
\hline
\end{tabular}

Source: Survey Data, 2020

Table 5 ranks the most affected areas during online learning using the mean. The results show that the respondents in rural areas faced more challenges in online learning than those in towns and the city of Kigali. This was mainly due to poor Internet connections, lack of data and an unstable electricity supply. These results concur with those of previous studies. For example, Caoa et al. (2020) demonstrate that students in rural areas are more marginalised when it comes to online learning than their counterparts in towns and cities. Daroedono et al. (2020) produced similar results. It is thus clear that COVID-I9 has led to learning inequality between students in rural and urban areas (also see Doyle, 2020).

Table 6: Test Statisticsa,

\begin{tabular}{|l|c|}
\hline & Challenges faced during online learning \\
\hline Chi-Square & 21.049 \\
\hline Df & 2 \\
\hline Asymp. Sig. & .000 \\
\hline
\end{tabular}

a. Kruskal Wallis Test

b. Grouping Variable: Location

Source: Survey Data, 2020

Table 6 shows the Kruskal Will's test of the significance of the challenges faced by students during online learning due to the COVID-Is pandemic. The results reveal that a lack of computers, lack of sufficient skills to study online, lack of data, poor Internet connections, an unconducive home learning environment, lack of electricity, and changes to the academic calendar have a statistically significant impact on the effective learning process of students based on their location.
Table 7: Significance test of the Impact of COVID-19 on students' Learning Process using ANOVA

\begin{tabular}{|c|c|c|c|c|c|c|}
\hline & & $\begin{array}{l}\text { Sum of } \\
\text { Squares }\end{array}$ & Df & $\begin{array}{l}\text { Mean } \\
\text { Square }\end{array}$ & $\mathrm{F}$ & Sig. \\
\hline \multirow{3}{*}{$\begin{array}{l}\text { Reduction in the } \\
\text { maintenance costs of } \\
\text { students during learning }\end{array}$} & Between Groups & 66.726 & 2 & 33.363 & 27.740 & .000 \\
\hline & Within Groups & 369.223 & 1097 & 1.203 & & \\
\hline & Total & 435.948 & 1099 & & & \\
\hline \multirow{3}{*}{$\begin{array}{l}\text { Affected the quality of } \\
\text { learning }\end{array}$} & Between Groups & 6.500 & 2 & 3.250 & 3.591 & .029 \\
\hline & Within Groups & 277.836 & 1097 & .905 & & \\
\hline & Total & 284.335 & 1099 & & & \\
\hline \multirow{3}{*}{$\begin{array}{l}\text { Lack of face-to-face } \\
\text { clarification }\end{array}$} & Between Groups & 22.301 & 2 & 11.150 & 9.310 & .000 \\
\hline & Within Groups & 367.686 & 1097 & 1.198 & & \\
\hline & Total & 389.987 & 1099 & & & \\
\hline \multirow{3}{*}{$\begin{array}{l}\text { Studying without } \\
\text { examinations }\end{array}$} & Between Groups & 3.700 & 2 & 1.850 & 1.292 & .276 \\
\hline & Within Groups & 439.771 & 1097 & 1.432 & & \\
\hline & Total & 443.471 & 1099 & & & \\
\hline \multirow{3}{*}{$\begin{array}{l}\text { Promoted independent } \\
\text { learning }\end{array}$} & Between Groups & 18.185 & 2 & 9.092 & 6.437 & .002 \\
\hline & Within Groups & 433.635 & 1097 & 1.412 & & \\
\hline & Total & 451.819 & 1099 & & & \\
\hline \multirow[t]{3}{*}{ Lack of group discussions } & Between Groups & 4.257 & 2 & 2.128 & 1.973 & .141 \\
\hline & Within Groups & 331.192 & 1097 & 1.079 & & \\
\hline & Total & 335.448 & 1099 & & & \\
\hline \multirow[t]{3}{*}{ Unable to do research } & Between Groups & 5.181 & 2 & 9.012 & 8.891 & .003 \\
\hline & Within Groups & 379.224 & 1077 & 1.723 & & \\
\hline & Total & 384.405 & 1099 & & & \\
\hline \multirow[t]{3}{*}{ Unable to do internship } & Between Groups & 6.349 & 2 & 12.010 & 11.992 & .000 \\
\hline & Within Groups & 831.920 & 1097 & 1.123 & & \\
\hline & Total & 838.269 & 1099 & & & \\
\hline \multirow{3}{*}{$\begin{array}{l}\text { COVID-19 affected the } \\
\text { academic calendar }\end{array}$} & Between Groups & 39.667 & 2 & 19.833 & 22.496 & .000 \\
\hline & Within Groups & 270.669 & 307 & .882 & & \\
\hline & Total & 310.335 & 309 & & & \\
\hline
\end{tabular}

Source: Survey Data 2020

Table 7 shows the impact of COVID-I9 on the students' learning process. As evidenced by P-values of less than $5 \%$, it illustrates that COVID-I9 has had a significant impact on maintenance costs for the students, face-to-face clarification, the quality of learning, independent learning, students' internships, 
students' research and the academic calendar. These results concur with those of previous studies. Zhanga et al. (2020) and Daniel (2020) show that the shift from face-to-face to online learning has affected the students' learning process, while Daroedono et al. (2020); Kapasiaa et al. (2020); Caoa et al. (2020); Calhoun (2020); Drane et al. (2020); and Owusu et al. (2020) note that COVID-ig led to changes in the academic calendar, especially for finalyear students. Naciri (2020), Chan (2020) and Abidah et al. (2020) observe that students doing science courses' quality of learning has been particularly hard hit due to the lack of virtual laboratories, library, cadavers, etc. Our study also shows that COVID-I9 negatively impacted group discussions and examinations. Drane et al. (2020) Owusu et al. (2020); Karalis (2020) and Brown et al. (2020) note that learning from peers through group discussions is fundamental to students' learning process. Moreover, formative and summative assessment are critical to this process.

\section{Conclusion and recommendations}

\section{Conclusion}

This study analysed the impact of the COVID-I9 pandemic on the learning process of students in Rwandan HEIs. The findings revealed that the pandemic has had numerous impacts on the learning process. While both positive and negative impacts were identified, the latter outweigh the former. The negative impacts include learning inequality among students, poor attendance of classes, lack of face-to-face clarification, studying without examinations, lack of group discussions, and inability to conduct research and undertake internships among final-year students.

Furthermore, the findings revealed that students in rural areas were more affected by poor Internet connections, a lack of data and a poor electricity supply than students in towns and the city of Kigali. This raises the worrying challenge of learning inequality between students from rural areas and those from towns.

The pandemic's positive impacts on the learning process of students in HEIs include promotion of independent learning; reduced maintenance costs of students during learning and improved technological skills.

\section{Recommendations}

The government should make concerted efforts to close the learning gap between students from towns, the city of Kigali and those from rural areas. This can be achieved by establishing learning centres in rural areas with full Internet connections. Furthermore, the government should improve Internet connectivity in rural areas and assist students from disadvantaged families with learning tools such as laptops and data.

For their part, HEIs should train students on online learning. A module should be introduced in first year to introduce students to online learning. Moreover, online learning should be part and parcel of all higher education offerings and modules should be delivered partly online and partly face-to-face.

\section{References}

Abidah, A., Hidaayatullah, H.N., Simamora, R.M., Fehabutar, D., and Mutakinati, L. (2020). Impact of Covid-Is pandemic to Indonesian education and its relation to the philosophy of Maerdeja Belajar. Studies in Philosophy of Sciences and Education, 1(I), pp 34-43 DOI: https://doi.org/ı0.46627/sipose.viiı.9.

Andersen, S.C., and Nielsen, H.S. (2019). Learning from Performance Information. Journal of Public Administration Research and Theory 3O(3), 4I5-43I.

Aziz K., and Ocius, D.M. (2020). Impact of Covid-19 on dental education in the USA. Wiley.

Bao, W. (2020). Six instructional strategies to summarise the current teaching experience for university instructors. Wiley.

Bjorklund, A, and Salvanes, K. (20II). Education and Family Background: Mechanisms and Policies. In: E. Hanushek, S. Machin and L. Woessmann (eds). Handbook of the Economics of Education, Vol. 3, pp. 20I-247.

Brown, N., Te Riele, K., Shelley, B., and Woodroffe, J. (2020). Learning at home during COVID-I9: Effects on vulnerable young Australians. Independent Rapid Response Report. Hobart: University of Tasmania, Peter Underwood Centre for Educational Attainment.

Calhoun, V. (2020). The impact of COVID-I9 on medical student surgical education: Implementing extreme pandemic response measures in a widely distributed surgical clerkship experience. The American Journal of Surgery 220(2020), 44-47.

Caoa, W., Ziwei, F., Guoqiang H., Mei H., Xinrong X., Jiaxin, D., and Jianzhong, Z. (2020). The psychological impact of the COVID-Ig epidemic on college students in China. National Library of Medicine, Elsevier 287 (2020). https://doi.org/Io.IoI6/j.psychres.2020.II2934

Chan, R.Y. (2020). Coronavirus and global higher education: Evidence for future research practice. Routledge Taylor and Francis.

Chick, R.C., Clifton, G.T., Peace, K.M., Propper, B.W., Hale, D.F., Alseidi, A.A., and Vreeland, T.J. (2020). Using Technology to Maintain the Education of Residents during the COVID-I9 Pandemic. Journal of Surgical Education 77(4), I-5 https://doi.org/Io.IoI6/j.jsurg.2020.03.018

Collis, J., and Hussey, R. (20I4) Business Research: A Practical Guide for Undergraduate and Postgraduate Students (4th ed.). Palgrave Macmillan.

Daniel, S.J. (2020). Education and the COVID-I9 pandemic. Springer Prospects 49 (2020), 9I-96. https://doi.org/I0.I007/SIII25-020-09464-3 
Daroedono, E., Forman, E.S., Muhammad, A., Jap, M.C., Evy, S.A., Robert, H.S., Trini, S., Lusia, S.S., Luana, N.A., Marwito, W., Linggom, K., and Hutabarat, R.S.O (2020). The impact of COVID-I9 on medical education: our students' perception on the practice of long distance learning. International Journal of Community Medicine and Public Health 7(7), 2790-2796.

Doyle, O. (2020). Covid-I9 exacerbating education inequality. Public Policy IE. Evidence for Policy 1(I), I-IO.

Drane, C., Vernon, L., and O'Shea, S. (2020). The impact of 'learning at home' on the educational outcomes of vulnerable children in Australia during the COVID-I9 pandemic. Literature Review prepared by the National Centre for Student Equity in Higher Education, Curtin University, Australia.

Gaspar, V., and Mauro, P. (2020). Fiscal Policies to Protect People During the Coronavirus Outbreak. IMF Blog, 5 March.

Georgieva, K. (2020). Potential Impact of the Coronavirus Epidemic: What We Know and What We Can Do. IMF Blog, 4 March.

Grafton, J., Lillis, A. M., and Mahama, H. (20II). Mixed methods research in accounting. Qualitative Research in Accounting and Management 8(I), 5-2I.

Hayes, S. (2020). China's Internationalized Higher Education During Covid-I9: Collective Student Autoethnography Postdigital Science and Education https://doi.org/I0.1007/s42438-020-00128-I

Joseph, C., Kerryn, B.H., Jurgen, R., Glowatz, J., Mathias, K., Burton, R., Magni, P., and Lam, S. (2020). Impact of Covid-I9 on the education institutions. Journal of Applied Teaching and Learning 3(2), II-I6.

Kapasiaa, N., Paulb, P., Royc, A., Sahac, J., Zaveric, A., Mallickc, R., Barmanc, M., Dasc, P., and Chouhanc, P. (2020). Impact of lockdown on learning status of undergraduate and postgraduate students during COVID-I9 pandemic in West Bengal, India. Children and Youth Services Review 16(2020), I-6.

Karalis, T. (2020), Planning and evaluation during educational disruption: lessons learned from Covid-I9 pandemic for treatment of emergencies in education. European Journal of Education Studies, ISSN: 250I-III, ISSN- L: 250I -IIII, doi: I0.528I/zenodo.3789022 Volume 7/ Issue 4/ 2020.

Kasomo, D. (2006). Research Methods in Humanities (Ist ed.). Egerton University Press Publishers.

Mulenga, E. M., and Marbán, J. M. (2020). Is COVID-I9 the Gateway for Digital Learning in Mathematics Education? Contemporary Educational Technology 12(2), ep269. https://doi.org/10.30935/cedtech/7949

Murphy, M.P.A. (2020). Covid-19 and the emergency of eLearning: consequences of securitisation of higher education for post pandemic pedagogy. Contemporary Security Policy. Routledge Taylor Francis.
Murphy, R., and Wyness, G. (2020). Minority Report: the impact of predicted grades on university admissions of disadvantaged groups. CEPEO Working Paper Series No 20-07 Centre for Education Policy and Equalising Opportunities, UCL Institute of Education.

Naciri, A., Baba, M., Achbani, A., and Kharbach, A. (2020). Role of mobile learning as a remote strategy to sustain teaching student centered learning. Journal Aquademia 4(I), I-Io https://doi.org/Io.29333/aquademia/8227

Nuno, F. (2020). Economic effect of Coronavirus outbreak on the world economy. Under Review.

Ogunode, Niyi Jacob, Abigeal, I., and Lydia, A. E. (2020). Impact of COVIDI9 on the Higher Institutions Development in Nigeria. Journal of Social Sciences and Humanities 2(II), 4-25.

Owusu, F.K., and Hanson, D. (2020). Impact of Covid-I9 on learning: the perspective of Ghanaian students. European Journal of Education Studies 7(3), I-I4.

Owusu-Fordjour, C., Koomson, C.K., and Hanson, D. (2020). The Impact of Covid-Is on Learning - The Perspective of the Ghanaian Student. European Journal of Education Studies 7(3), I-I4.

Özer, M. (2020). Educational Policy Actions by the Ministry of National Education in the times of COVID-I9. Kastamonu Education Journal 28(3), II24-II29. doi:10.24106/kefdergi.722280

Ozil, P., and Aruna, T. (2020). Spillover of Covid-19 impact on the global economy. MPRA paper No. 99850.

Peters, M.A., Wang, H., Ogunniran, M.O. Yingying, H., Benjamin G., Jasmin O.C., Eric, A. Q., Zhihong, R., Stephanie, H., Chunxiao, M., Sphiwe, W.K., Man, Z., Shuchen Z., Amina, L., Wener, Z., Rulin, X., and Liz, J. (2020). China's Internationalisation of higher education during Covid. Post Digital Science and Education. Springer Science and Business LLC. https://doi.org/I0.1007/s42438-020-00128-I.

Piopiunik, M. Schwerdt, G. Simon, L., and Woessman, L. (2020). Skills, signals, and employability: An experimental investigation. European Economic Review 123(C), https://econpapers.repec.org/scripts/redir. pf?u=https\%3A\%2F\%2Fdoi.org\%2Fio.IOI6\%252Fj.euroecorev.2020 .I03374; h=repec:eee:eecrev:v:I23:y:2020:i:c:sool4292120300064.

Radwan, A., and Radwan, E. (2020). Social and Economic Impact of School Closure during the Outbreak of the COVID-I9 Pandemic: A Quick Online Survey in the Gaza Strip. Pedagogical Research 5(4), emoo68. https://doi.org/I0.29333/pr/8254

Reimers, F.M., and Schleicher, A. (2020). A framework to guide an education response to the COVID-I9 Pandemic of 2020. OECD Report.

Rumbley, L.E. (2020). Coping with COVID-I9: International higher 
education in Europe. The European Association for International Education (EAIE).

Saunders, M., Lewis, P., and Thornhill, A. (2012). Research Methods for Business Students (6th ed.). Pearson Education Limited.

Sintema, E. J. (2020). E-Learning and Smart Revision Portal for Zambian Primary and Secondary School Learners: A Digitalized Virtual Classroom in the COVID-I9 Era and Beyond. Aquademia 4(2), ep200I7. https://doi.org/Io.29333/aquademia/8253

Tomaz, C., Leland, C., Ryan, A.D., and Adrian, H.P. (2020). Tracking the labour market development during the Covid-19 pandemic. A preliminary assessment. Finance and Economic Discussion Series. Division of Research, Statistics and Monetary affairs. Federal Reserve Washington DC

Toquero, C.M. (2020). Challenges and opportunities for higher education institutions amid the Covid-I9 pandemic. Pedagogical Research 5(4), I-5.

Twesige, D., Gasheja, F., and Barayandema, J. (2020). Effects of tax incentives on the growth of SMEs in Rwanda. Springer Publications.

Wang, C., Cheng, Z.X., Yue, G., and McAleed, M. (2020). Risk management of Covid-I9 by Universities. Journal of Risk Management (MDPI) I3(2), 36-42.

Wargadinata, W., Maimunah, I., Dewi, E., and Rofiq, Z. (2020). Student's Responses on Learning in the Early COVID-I9 Pandemic. Tadris: Jurnal Keguruan dan Ilmu Tarbiyah 5(I), I4I-I53. DOI: I0.24042/tadris. v5i1.6I53

William, J., Hueston, M.D, Elizabeth, M., and Petty, M.D. (2020). The Impact of the COVID-I9 Pandemic on Medical Student Education in Wisconsin. Medical Journal 119(2), 80-82

Wilson, J. (2010). Essentials of Business Research: A Guide to Doing Your Research Project. Sage Publications.

Zhang, W., Yuxin, W., Lili, Y., and Chuanyi, W. (2020). Suspending Classes Without Stopping Learning: China's Education Emergency Management Policy in the COVID-I9 Outbreak. Journal of Risk and Financial Management 13(55), I-6. Doi I03390/jrfm I3030055 